\title{
ANALISIS ABRASI DAN AKRESI PERAIRAN PANTAI BARUS TAPANULI TENGAH DENGAN MODEL CEDAS 2.0
}

\author{
Novi Andhi Setyo Purwono \\ Program Studi Teknik Sipil, Fakultas Teknik, Universitas Wijayakusuma Purwokerto \\ Email: novi_andhisp@yahoo.com
}

\begin{abstract}
ABSTRAK
Barus merupakan daerah yang sebagian besar masyarakatnya adalah nelayan, hal ini dikarenakan Barus merupakan daerah yang terletak di pinggir pantai. Kondisi eksisting menunjukkan garis pantai di sisi timur bangunan tembok laut, kondisi garis pantai mengalami abrasi yang berakibat mundurnya garis pantai dan hampir menjangkau kawasan bangunan rusun nelayan, hal ini akibat adanya bangunan pelabuhan berupa trester masif yang menjorok ke laut mengakibatkan suplai sedimen ke kawasan rusun tertahan dan garis pantai mengalami kemunduran. Untuk menjaga kestabilan garis pantai maka perlu dilakukan suatu upaya penanganan untuk mengendalikan daya rusak air di kawasan ini. Model garis pantai merupakan contoh prakiraan numerik yg didasarkan dalam persamaan kontinyuitas sedimen dan persamaan laju angkutan sedimen sepanjang pantai. Laju angkutan sedimen sepanjang pantai adalah fungsi berdasarkan variasi tinggi dan arah gelombang sepanjang pantai yang terbentuk karena imbas refraksi dan difraksi. Hasil model perubahan garis pantai dengan perlindungan kawasan rusun nelayan dari gelombang dengan membuat bangunan tembok laut adalah sisi sebelah timur rusun nelayan terjadi abrasi $\pm 7 \mathrm{~m}$ dan sedimentasi $\pm 5 \mathrm{~m}$, daerah depan rusun nelayan tidak terjadi sedimentasi maupun abrasi, sisi sebelah Barat rusun nelayan tidak terjadi sedimentasi maupun abrasi, sisi timur Dermaga Barus tidak terjadi abrasi maupun sedimentasi, daerah Dermaga Barus terjadi sedimentasi $\pm 20 \mathrm{~m}$, dan sisi Barat Dermaga Barus terjadi sedimentasi $\pm 9 \mathrm{~m}$. Hasil tersebut menunjukkan bahwa untuk kondisi penanganan dengan membuat tembok laut di depan kawasan rusun menunjukkan bahwa lokasi tersebut aman terhadap gerusan gelombang.
\end{abstract}

Kata kunci: Abrasi-akresi Pantai, Barus, Cedas 2.0

\begin{abstract}
Barus is an area where most of the people are fishermen, this is because Barus is an area located on the coast. The existing condition shows the shoreline on the east side of the seawall building, the condition of the shoreline is experiencing abrasion resulting in the retreat of the coastline and almost reaches the fisherman's flat building area, this is due to the port building in the form of a massive trester jutting into the sea resulting in sediment supply to the retained flat towers and the coastline has declined.To maintain the stability of the coastline, it is necessary to make an effort to control the damage to water in this area. The shoreline model is a numerical forecast model based on the sediment continuity equation and the sediment transport rate equation along the coast. Sediment transport rates along the coast are a function of the variation in height and direction of waves along the coast formed by the effects of refraction and diffraction. The results of the shoreline change model with the protection of the fisherman's flat area from waves by building sea walls is the east side of the fisherman's towers abrasion $\pm 7 \mathrm{~m}$ and sedimentation $\pm 5 \mathrm{~m}$, the front area of the fisherman's towers does not occur sedimentation or abrasion, the western side of the fisherman's towers does not sedimentation and abrasion occurred, the east side of Barus Jetty did not occur abrasion or sedimentation, the area of Barus Jetty occurred $\pm 20 \mathrm{~m}$ sedimentation, and the west side of Barus Jetty occurred sedimentation $\pm 9 \mathrm{~m}$. These results indicate that for handling conditions by making a seawall in front of the flat area shows that the location is safe from scouring of waves.
\end{abstract}

Keywords: Beach Abrasion-Accretion, Barus, Cedas 2.0 


\section{Pendahuluan}

Barus merupakan daerah yang sebagian besar masyarakatnya adalah nelayan. Hal ini dikarenakan Barus merupakan daerah yang terletak di pinggir pantai. Titik fokus dalam kajian ini adalah Pantai Barus yang ada di Kabupaten Tapanuli Tengah Provinsi Sumatera Utara. Kabupaten Tapanuli Tengah terletak antara 1011'00" - 2022'00" Lintang Utara dan 980 07’00”- 98012’00” Bujur Timur (Gambar 1).

Beberapa tahun yang lalu di pinggir pantai barus telah dibangun beberapa buah krib sebagai pengaman pantai yang mengakibatkan garis pantai di sekitar krib bertambah ke arah laut. Sekitar 5 tahun yang lalu Direktorat Jenderal Cipta Karya membangun rusun nelayan di pinggir pantai Barus. Sejalan dengan itu Pemerintah Daerah membangun dermaga di pantai Barus yang mengakibatkan kemunduran garis pantai. Kemunduran garis pantai berdampak pada posisi rusun terutama pada saat air saat pasang.

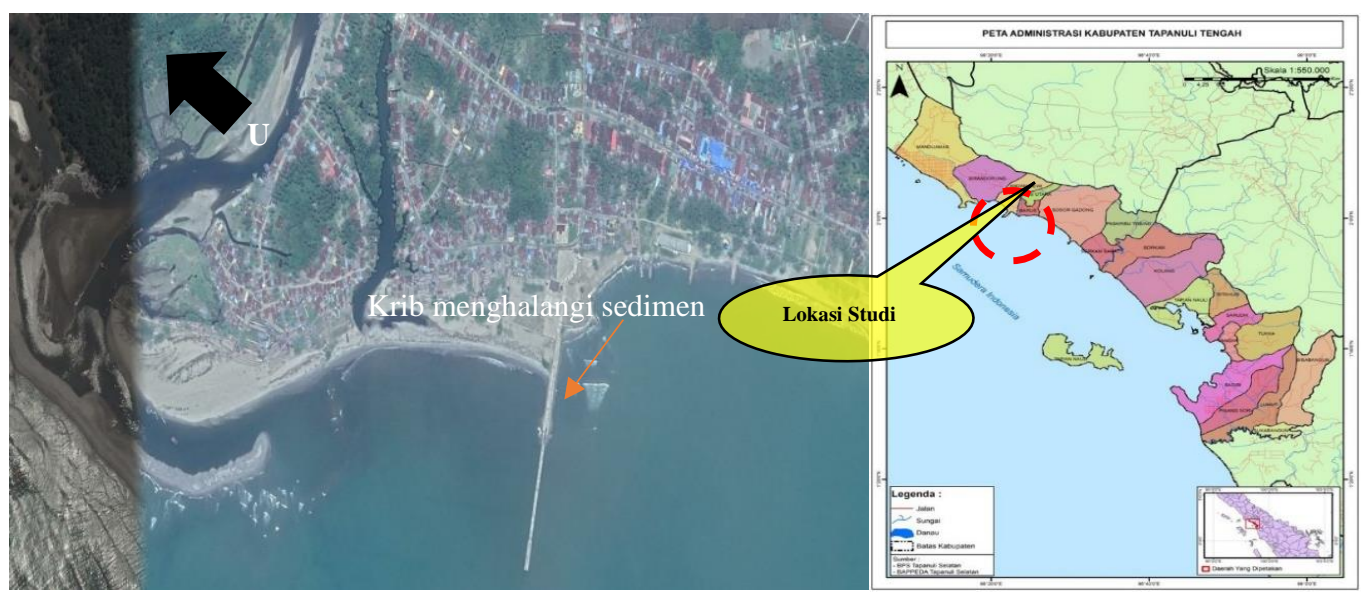

Gambar 1. Lokasi Studi (Google Earth, 2019) dan BPS dan BAPPEDA Kabupaten Tapanuli Tengah)

Gambar 2 menunjukkan garis pantai di sisi timur bangunan tembok laut, kondisi garis pantai mengalami abrasi yang berakibat mundurnya garis pantai dan hampir menjangkau kawasan bangunan rusun nelayan. Hasil wawancara dengan Kepala Desa setempat, saat mulai dibangun rusun nelayan posisi garis pantai berada kurang lebih $100 \mathrm{~m}$ dari bangunan. Kondisi saat ini yang terjadi akibat adanya bangunan pelabuhan berupa trester masif yang menjorok ke laut mengakibatkan suplai sedimen ke kawasan rusun tertahan dan garis pantai mengalami kemunduran. Ketika belum ada bangunan menjorok ke laut yang dibangun oleh pelabuhan, pergerakan sedimen yang keluar masuk kawasan tersebut akibat gelombang seimbang, tetapi setelah ada bangunan pergerakan sedimen yang keluar dan masuk menjadi tidak seimbang sehingga garis pantai mengalami abrasi. Saat ini 
kondisi garis pantai dilihat pada waktu air laut surut hanya berkisar $10 \mathrm{~m}$ dari bangunan rusun nelayan sehingga akan membahayakan stabilitas bangunan tersebut.

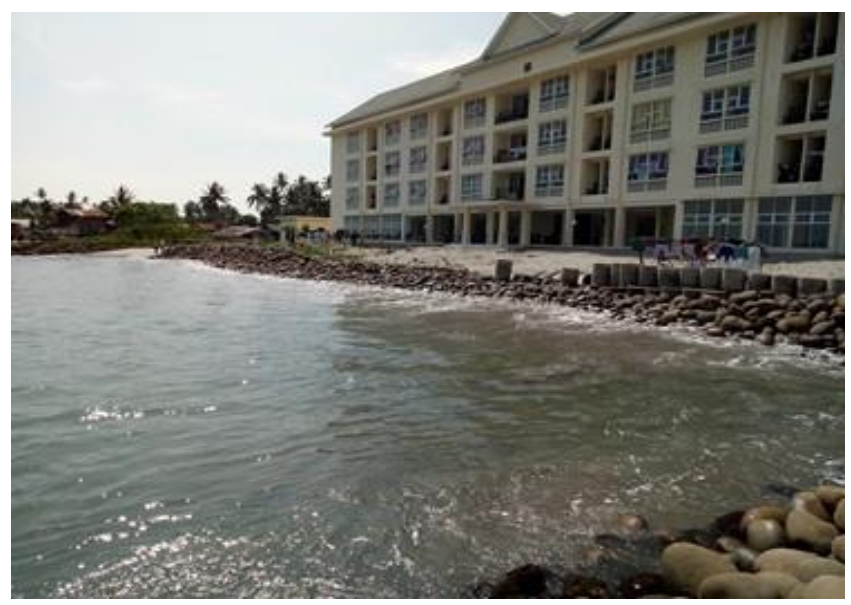

Gambar 2. Abrasi di Depan Rusun

Untuk menjaga kestabilan garis pantai maka perlu dilakukan suatu upaya penanganan untuk mengendalikan daya rusak air di kawasan ini. Salah satu penyebab mundurnya garis pantai adalah berkurangnya suplai sedimen dari Sungai Sirahan dan akibat transformasi gelombang yang membawa material sedimen keluar dari kawasan perairan daerah rusun, sehingga perlindungan alami ada dunes terkikis oleh gelombang.

\section{TINJAUAN PUSTAKA}

Gelombang adalah bentuk energi yang dapat membentuk pantai, menyebabkan arus dan transportasi sedimen pada arah tegak lurus dan di sepanjang pantai sehingga menyebabkan gaya bekerja di bangunan pesisir. Gelombang di alam memiliki bentuk yang sangat kompleks terdiri dari spektrum gelombang di mana masing-masing memiliki periode tinggi dan berbeda. Untuk keperluan perencanaan, data gelombang diperlukan dalam interval panjang minimum 5 tahun dan lebih baik lagi jika tersedia data gelombang selama 10 tahun. Data gelombang yang cukup panjang sangat sulit diperoleh di lapangan, pendekatan yang dilakukan untuk mendapatkan data gelombang di lapangan adalah dengan mengolah data angin dari Badan Meteorologi, Klimatologi dan Geofisika (BMKG) di lokasi studi (Purwono, 2018).

Pengukuran kecepatan angin oleh BMKG dilakukan dengan melakukan, dalam persamaan atau dalam grafik pembangkitan gelombang data dari data yang digunakan adalah data angin di atas laut. Angin bertiup pada permukaan awal tenang, akan menyebabkan gangguan pada permukaan dan menyebabkan riak gelombang. Jika 
kecepatan angin meningkat, riak gelombang akan lebih besar, dan jika angin bertiup terus menerus, pada akhirnya akan membentuk gelombang (CERC, 2016).

Untuk mendukung rencana pelabuhan dan keamanan bangunan pesisir, data hidrooseanografi diperlukan, termasuk data gelombang di lapangan dengan interval waktu yang lama. Untuk mendapatkan data gelombang di lapangan dengan interval waktu yang Panjang cukup sulit dan mahal, sehingga pendekatan yang dapat dilakukan untuk mendapatkan data gelombang adalah analisis perkiraan data gelombang menggunakan data angin dari stasiun pencatatan angin yang lebih dekat. Salah satu gaya utama yang menyebabkan terjadinya gelombang adalah akibat adanya hembusan angin. Angin yang berhembus di atas permukaan air akan memindahkan energinya ke air. Kecepatan angin akan menimbulkan tegangan pada permukaan laut, sehingga permukaan air yang semula tenang akan terganggu dan timbul riak gelombang. Apabila kecepatan angin bertambah riak tersebut menjadi semakin besar, dan apabila angin berhembus terus menerus akan terbentuk gelombang. Semakin lama dan semakin kuat angin berhembus, semakin besar pula gelombang yang terbentuk. Gelombang yang terjadi di daerah pembangkitan disebut gelombang $S E A$, sedangkan gelombang yang terbentuk tersebut setelah menjalar keluar daerah pembangkitan disebut gelombang SWELL (CERC, 2001).

Tinggi dan periode gelombang yang ditinggikan oleh angin, dipengaruhi oleh kecepatan angin (U), panjang angin (TD), arah angin dan panjang fetch (F). Fetch adalah panjang daerah pembangkitan gelombang pada arah kecepatan angin tersebut berhembus

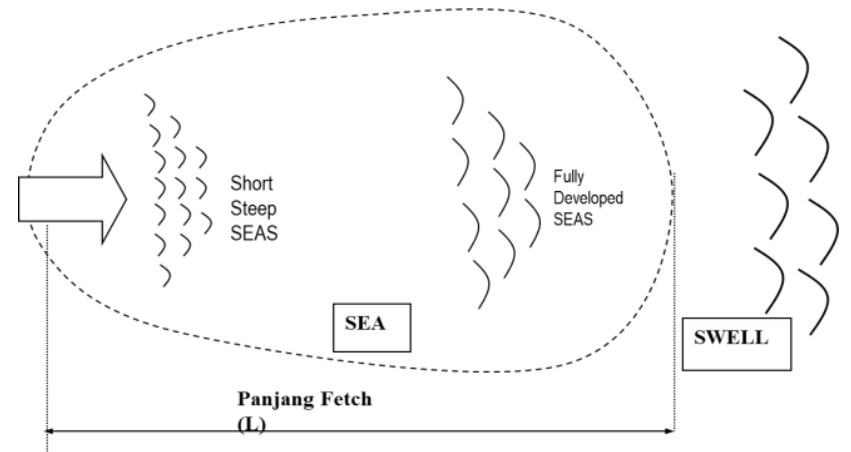

Gambar 3. Pembentukan Gelombang Angin (sumber: CERC, 2001)

\subsection{Data Angin}

Data angin diperoleh dengan mengukur kecepatan angin setiap kali menggunakan anemometer di area tersebut. Data angin yang digunakan untuk perkiraan ombak adalah data di permukaan laut di lokasi pembangkitan. Data dapat diperoleh dari pengukuran 
langsung pada permukaan laut atau pengukuran darat, dekat dengan lokasi yang akan menjadi data angin di laut. Kecepatan angin diukur dengan anemometer dan umumnya dinyatakan dalam knot. Sebuah simpul adalah menit panjang melalui Khatulistiwa yang ditempatkan dalam satu jam, atau $1 \mathrm{knot}=1.852 \mathrm{~km} / \mathrm{jam}=0,5 \mathrm{~m} / \mathrm{dt}$. Data angin dicatat setiap jam dan secara umum disajikan dalam tabel. Dengan rekaman waktu angin, akan dapat mengetahui angin dengan kecepatan tertentu dan durasinya, kecepatan maksimum kecepatan angin, arah angin dan juga dapat dihitung dengan kecepatan angin rata-rata harian.

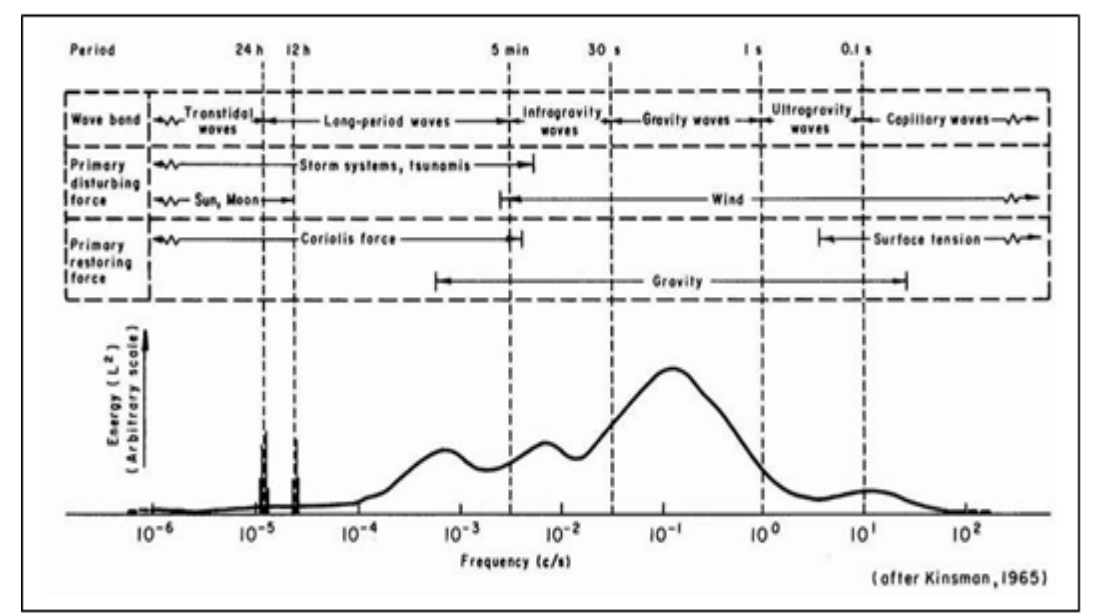

Gambar 4. Distribusi energi pembangkit gelombang laut (sumber: CERC, 2001)

Jumlah data angin yang dikumpulkan dalam bentuk tabel untuk beberapa tahun pengamatan adalah sangat besar. Untuk itu data harus diolah dan disajikan dalam bentuk tabel ringkasan atau diagram yang disebut dengan windrose. Penyajian serupa ini dapat dibuat dalam bentuk bulanan, tahunan atau bahkan untuk beberapa tahun pencatatan. Dengan tabel atau windrose tersebut maka karakteristik angin dapat dibaca dengan cepat dan mudah.

\subsection{Konversi Angin}

Data angin yang didapatkan dari pengukuran di permukaan laut memakai perahu atau kapal yang bergerak atau mengukur di daratan (misalnya di pelabuhan udara). Pengukuran data angin di permukaan laut adalah yang paling cocok untuk peramalan gelombang. Biasanya pengukuran angin dilakukan di daratan sementara rumus-rumus pembangkitan gelombang mengasumsikan angin yang terjadi di atas laut. Oleh karena itu diperlukan transformasi dari data angin di daratan yang terdekat dengan lokasi studi ke data 
angin di atas permukaan laut. Hubungan antara angin di atas laut dan di daratan terdekat diberikan oleh persamaan $R_{L}=U_{W} / U_{L}$ seperti dalam Gambar 5. Gambar tersebut merupakan hasil penelitian yang dilakukan di Great Lake, Amerika Serikat. Grafik tersebut dapat digunakan untuk daerah lain kecuali apabila karakteristik daerah sangat berlainan. Rumus-rumus dan grafik-grafik pembangkitan gelombang mengandung variabel $\mathrm{U}_{\mathrm{A}}$, yaitu faktor tegangan angin (wind-stress factor) yang dapat dihitung dari kecepatan angin. Setelah dilakukan berbagai konversi kecepatan angin seperti yang dijelaskan di atas, kecepatan angin dikonversikan pada faktor tegangan angin dengan menggunakan rumus berikut:

$$
U_{A}=0,71 \cdot U^{1,23}
$$

dimana $\mathrm{U}$ adalah kecepatan angin dalam $\mathrm{m} / \mathrm{d}$.

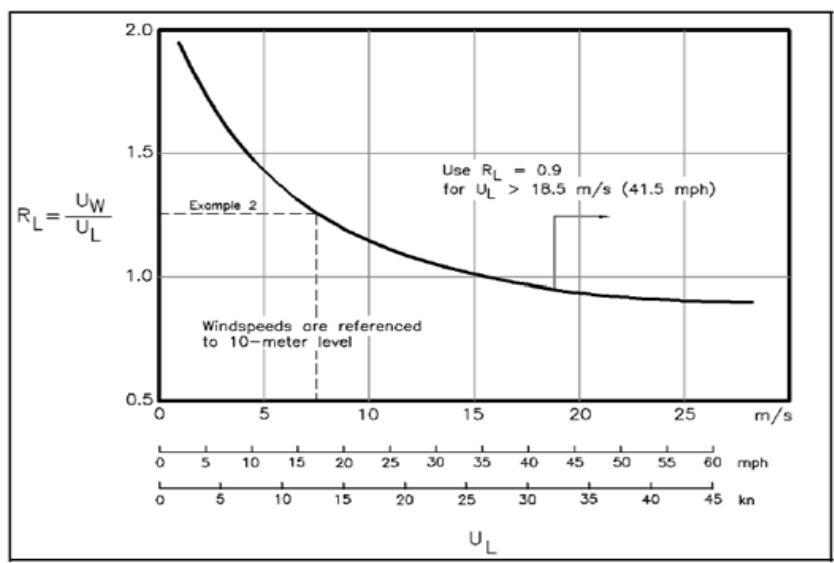

Gambar 5. Hubungan Antara Kecepatan Angin di Laut dan Darat (sumber : SPM, 1984)

\subsection{Peramalan Gelombang}

\subsubsection{Penentuan Fetch}

Untuk melakukan peramalan gelombang di suatu perairan diperlukan masukan berupa data angin dan peta batimetri. Peta perairan lokasi dan sekitarnya diperlukan untuk menentukan besarnya fetch atau kawasan pembentukan gelombang. Fetch adalah daerah pembentukan gelombang yang diasumsikan memiliki kecepatan dan arah angin yang relatif konstan. Adanya kenyataan bahwa angin bertiup dalam arah yang bervariasi atau sembarang, maka panjang fetch diukur dari titik pengamatan dengan interval $5^{\circ}$.

Panjang fetch efektif dihitung untuk 8 arah mata angin dan ditentukan berdasarkan rumus berikut. 


$$
L f_{i}=\frac{\sum L f_{i} \cdot \cos \alpha_{i}}{\sum \cos \alpha_{i}}
$$

dimana

$L f_{i}=$ panjang fetch ke-i

$\alpha_{i}=$ sudut pengukuran fetch ke-i

$i=$ jumlah pengukuran fetch

Jumlah pengukuran " $i$ " untuk tiap arah mata angin tersebut meliputi pengukuranpengukuran dalam wilayah pengaruh fetch $\left(22,5^{\circ}\right.$ searah jarum jam dan $22,5^{\circ}$ berlawanan arah jarum jam dari masing-masing arah mata angin), (SPM, 1984).

\subsubsection{Perhitungan Gelombang}

Untuk melakukan peramalan gelombang di suatu perairan diperlukan masukan berupa data angin dan peta batimetri. Pembentukan gelombang pada perairan yang dalam (deep water waves) dianalisa dengan rumus di bawah ini. Langkah metode peramalan ini dapat digunakan pada situsi gelombang tidak terbentuk penuh (non fully developed sea), baik untuk kondisi fetch terbatas (fetch limited condition), maupun kondisi durasi terbatas (duration limited condition) sebagai berikut (CERC 2016):

$$
\begin{aligned}
& \frac{g t_{d}}{U_{A}}=68.8\left(\frac{g F}{U_{A}^{2}}\right)^{2 / 3} \leq 7.5 \times 10^{4} \\
& \frac{g H_{m_{0}}}{U_{A}^{2}}=0.0016\left(\frac{g F}{U_{A}^{2}}\right)^{1 / 2} \leq 0.2433 \\
& \frac{g T_{p}}{U_{A}^{2}}=0.2857\left(\frac{g F}{U_{A}^{2}}\right)^{1 / 3} \leq 8.134
\end{aligned}
$$

Sedangkan persamaan untuk keadaan gelombang terbentuk penuh diberikan oleh:

$$
\begin{aligned}
& \frac{g t_{d}}{U_{A}}=7.5 \times 10^{4} \\
& \frac{g H_{m_{0}}}{U_{A}^{2}}=0.2433 \\
& \frac{g T_{p}}{U_{A}^{2}}=8.134
\end{aligned}
$$

dimana:

$t_{d} \quad=$ durasi angin

$H_{m 0} \quad=$ tinggi gelombang signifikan menurut

energi spektral

$T_{p} \quad=$ periode puncak gelombang 


$$
\begin{aligned}
T_{s}= & \text { periode gelombang signifikan } \\
T_{s}= & 0.95 T_{p} \\
U_{A}= & 0.71 U_{10} 1.23 \mathrm{~m} / \text { detik = faktor tekanan } \\
& \text { angin } \\
U_{10}= & \text { kecepatan angin pada ketinggian } 10 \mathrm{~m}
\end{aligned}
$$

Langkah-langkah yang dilakukan untuk peramalan gelombang ini adalah :

1. Diketahui : $\mathrm{U}_{\mathrm{A}}$ (wind stress factor), $\mathrm{F}$ (panjang fetch efektif), dan $\mathrm{t}$ (durasi = lamanya angin bertiup).

2. Jika didapatkan :

a. Durasi data $(\mathrm{t})>\mathrm{t}_{\mathrm{c}} \rightarrow$ Fetch Limited (FL)

b. Durasi data $(\mathrm{t})<\mathrm{t}_{\mathrm{c}} \rightarrow$ Time Limited $(\mathrm{TL})$

3. Untuk kondisi Fetch Limited $\left(\mathrm{F}_{\mathrm{L}}\right)$

- Hitung $\mathrm{H}$ dari rumus (1)

- Hitung T dari rumus (2)

4. Untuk kondisi Time Limited $\left(\mathrm{T}_{\mathrm{L}}\right)$

- Hitung $\mathrm{F}_{\min }$ dari rumus (4)

- Hitung $\mathrm{H}$ dengan menggunakan rumus (1), dengan nilai $\mathrm{F}=\mathrm{F}_{\min }$

- Hitung $\mathrm{T}$ dengan menggunakan rumus (2), dengan nilai $\mathrm{F}=\mathrm{F}_{\min }$

5. Nilai $\mathrm{H}$ dan $\mathrm{T}$ yang didapat dari ramalan adalah :

- Nilai $\mathrm{H} \rightarrow \mathrm{H}=\mathrm{H}^{1 / 3}=\mathrm{H}_{\mathrm{s}}=$ tinggi gelombang signifikan

- $\quad$ Nilai $\mathrm{T} \rightarrow \mathrm{T}=\mathrm{T}_{\mathrm{p}}=$ periode puncak spektrum gelombang

Keterangan : $\mathrm{T}_{\mathrm{s}} \approx 0,95 \mathrm{~T}_{\mathrm{p}} \rightarrow \mathrm{T}_{\mathrm{s}}=$ tinggi gelombang signifikan.

\subsubsection{Penentuan Gelombang Kala Ulang}

Prosedur yang cukup penting pada saat perancangan adalah peramalan besarnya gelombang rencana relatif terhadap umur rencana (design life) dari struktur dan keamanan yang diharapkan. Berdasarkan data yang tidak lengkap, situasi ekstrem yang harus diestimasi dari ekstrapolasi data yang dimiliki. Proses ini sama dengan meramalkan debit banjir dengan periode ulang 50 tahun pada hidrologi. Dua metoda yang biasa digunakan untuk mengestimasoi probabilitas nilai ekstrem ini adalah metoda Lognormal atau metode Gumbel (Triatmodjo, B, 1999).

Untuk memperoleh tinggi gelombang ekstrim pada periode waktu tertentu, perlu melakukan analisis frekuensi tinggi gelombang dengan beberapa tipe fungsi distribusi nilai ekstrim, antara lain: 


\section{Distribusi Log Normal}

Fungsi probabilitas densitas dari distribusi Log Normal dinyatakan dalam persamaan berikut ini :

$$
\begin{gathered}
f(H)=\frac{1}{\sigma H \sqrt{2 \pi}} \exp \left[-\frac{(\ln H-\mu)^{2}}{2 \sigma^{2}}\right] ; \quad 0 \leq H<\infty \\
\sigma^{2}=\frac{1}{N-1} \sum_{i=1}^{N}\left(H_{i}-\bar{H}\right)^{2}
\end{gathered}
$$

keterangan :

$$
\begin{array}{ll}
\mu & =\text { nilai rata-rata } \\
\sigma & =\text { standar deviasi } \\
\mathrm{H} & =\text { variabel bebas }=\text { tinggi gelombang }
\end{array}
$$

\section{Distribusi Pearson III}

Distribusi Pearson III diturunkan dari suatu fungsi Gamma yang mempunyai 3 parameter. Persamaanya adalah sebagai berikut :

$$
f(H)=\frac{\lambda^{\beta}(H-\varepsilon)^{\beta-1} \exp [-\lambda(H-\varepsilon)]}{\gamma(\beta)}
$$

dimana :

$$
\begin{aligned}
& \lambda=\frac{s_{H}}{\sqrt{\beta}} \quad \beta=\left(\frac{2}{C_{S}}\right) \quad \varepsilon=\bar{H}-s_{H} \sqrt{\beta} \\
& Y(\beta)=\int_{-\infty}^{\infty} H^{\beta-1} \exp (-\lambda) d H \quad C_{s}=\text { koefisien asimetri }
\end{aligned}
$$

\section{Distribusi Gumbel}

Langkah perhitungan metode Gumbel sebagai berikut :

$$
\begin{aligned}
& \sigma^{2}=\frac{1}{\mathrm{~N}-1} \sum_{\mathrm{i}=1}^{\mathrm{N}}\left(\mathrm{H}_{\mathrm{i}}-\overline{\mathrm{H}}\right)^{2} \mathrm{~K}_{\mathrm{r}}=-\frac{\sqrt{6}}{\pi}\left(0.5772+\ln \left(\ln \left(\frac{\mathrm{T}}{\mathrm{T}-1}\right)\right)\right) \\
& \mathrm{H}_{\mathrm{r}}=\overline{\mathrm{H}}+\mathrm{K}_{\mathrm{r}} \cdot \sigma
\end{aligned}
$$

keterangan :

$$
\begin{array}{ll}
\overline{\mathbf{H}} & =\text { tinggi gelombang rata-rata } \\
\mathrm{T} & =\text { periode ulang } \\
\mathrm{N} & =\text { jumlah data gelombang } \\
\sigma & =\text { standar deviasi }
\end{array}
$$


$\mathrm{H}_{\mathrm{T}} \quad$ = tinggi gelombang dengan periode ulang tertentu

$\mathrm{Kt} \quad=$ Koefisien Gumbel

\subsubsection{Perubahan Garis Pantai}

Model pantai adalah model numerik berdasarkan persamaan kontinuitas sedimen dan persamaan laju transportasi sedimen di sepanjang pantai. Tingkat transportasi sedimen di sepanjang pantai adalah fungsi variasi tinggi dan arah gelombang di sepanjang pantai yang terbentuk karena pengaruh refraksi dan difraksi. Pada model garis pantai tidak digambarkan angkutan yang dihasilkan oleh arus pasang surut, angin atau sumber gaya lainnya. Hal ini menunjukkan bahwa model sebaiknya digunakan jika gelombang pecah merupakan mekanisme yang dominan dalam angkutan sedimen sepanjang pantai.

Model pantai hanya dapat digunakan untuk memperkirakan evolusi pantai dengan mengangkut sedimen di sepanjang pantai dalam skala waktu yang lama dan ruang berskala besar. Ini terutama menggambarkan erosi dan akresi di sekitar bangunan pantai, seperti groin, jetty, dermaga dan pemecah lepas pantai (pemecah breakwater terpisah) yang disebabkan oleh menghalangi transportasi sedimen yang sejajar dengan pantai.

Perangkat lunak yang digunakan pada pemodelan ini menggunakan model CEDAS 2.0 dengan modul nemos. Input data berupa koordinat XYZ hasil survey bathimetri dan topografi, tinggi gelombang, periode gelombang dan arah gelombang perairan Barus. Ukuran grid permodelan adalah 10 meter dengan panjang daerah permodelan arah X adalah 3.500 meter dan arah Y adalah 2.500 meter, luas daerah permodelan adalah $8.750 .000 \mathrm{~m} 2$ Seperti tersaji pada Gambar 5 berikut. Running model perubahan garis pantai dilakukan terhadap semua arah datang gelombang yang dapat terjadi di perairan Barus. Permodelan dilakukan secara time series selama 10 tahun. Data-data yang dibutuhkan untuk analisis model adalah : data bathimetri, data angin, data ukuran butir sedimen, dan data topografi.

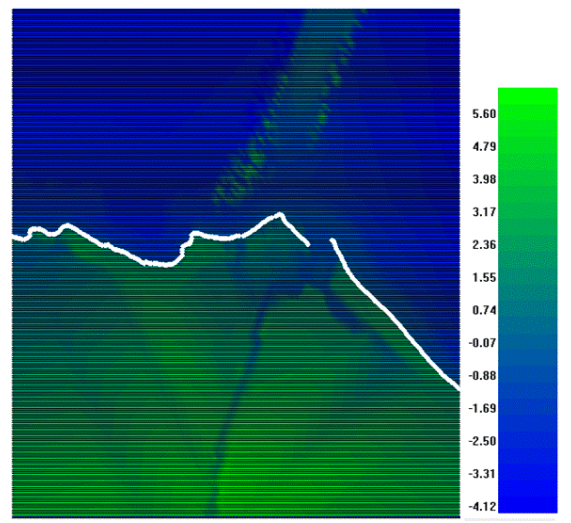

Gambar 6. Grid Permodel Perubahan Garis Pantai Perairan Barus 


\section{HASIL DAN PEMBAHASAN}

\subsection{Hasil Analisis Angin}

Perairan Barus adalah daerah yang memiliki fitur ombak laut, yaitu, ombak terbentuk tidak jauh dari lokasi pembentukan. Ini dapat dilihat di mana posisi perairan berada di area yang dilindungi dari beberapa pulau, jadi jika pencarian yang diekstrak tidak akan mendapatkan kondisi pemulihan maksimum ( $\geq 200 \mathrm{~km})$ karena sisi utara terhambat oleh pulau-pulau dan benua itu Oleh karena itu, persamaan yang digunakan untuk menghitung gelombang adalah persamaan dari laut yang sepenuhnya berkembang.

Tabel 1. Data Angin Perairan Pantai Barus Tahun 2005-2009 (BMKG Sinaboi)

\begin{tabular}{lrrrrrrrrrr} 
& \multicolumn{2}{c}{2005} & \multicolumn{2}{c}{2006} & \multicolumn{2}{c}{2007} & \multicolumn{2}{c}{2008} & \multicolumn{2}{c}{2009} \\
\cline { 2 - 11 } Bulan & \multicolumn{1}{c}{ Kec } & Arah & \multicolumn{1}{c}{ Kec } & Arah & Kec & Arah & Kec & Arah & Kec & Arah \\
\cline { 2 - 11 } & (knots) & & (knots) & & (knots) & & $($ knots $)$ & & (knots) \\
\hline JAN & 10.79 & 180.90 & 10.51 & 284.57 & 10.82 & 225.24 & 9.78 & 263.82 & 13.36 & 288.19 \\
FEB & 9.33 & 165.89 & 10.03 & 246.95 & 9.72 & 181.75 & 12.72 & 300.69 & 9.29 & 281.25 \\
MAR & 8.58 & 183.94 & 7.26 & 234.36 & 7.16 & 238.36 & 6.11 & 150.00 & 5.42 & 222.26 \\
APR & 4.90 & 174.92 & 5.29 & 205.31 & 4.53 & 158.88 & 5.29 & 144.01 & 5.89 & 174.41 \\
MEI & 9.82 & 141.55 & 6.76 & 150.69 & 7.39 & 133.17 & 9.88 & 144.69 & 6.49 & 167.09 \\
JUNI & 10.21 & 146.33 & 10.69 & 139.98 & 8.28 & 152.37 & 9.64 & 145.34 & 9.89 & 141.69 \\
JULI & 11.04 & 151.17 & 13.83 & 147.87 & 9.98 & 147.47 & 11.79 & 137.74 & 11.80 & 140.88 \\
AGS & 12.31 & 150.13 & 15.28 & 144.05 & 13.08 & 141.08 & 10.53 & 129.53 & 11.63 & 139.08 \\
SEP & 11.21 & 151.81 & 13.20 & 139.50 & 11.68 & 149.31 & 9.90 & 141.38 & 10.46 & 139.43 \\
OKT & 7.19 & 179.26 & 9.93 & 139.05 & 7.96 & 151.54 & 6.13 & 141.13 & 6.74 & 144.55 \\
NOV & 6.94 & 216.50 & 4.45 & 156.07 & 7.11 & 211.54 & 5.53 & 220.46 & 6.97 & 220.86 \\
DES & 8.87 & 260.77 & 6.80 & 196.03 & 9.67 & 273.19 & 10.76 & 294.90 & 5.29 & 197.15 \\
\hline
\end{tabular}

Tabel 2. Data Angin Perairan Pantai Barus Tahun 2010-2014 (BMKG Sinaboi)

\begin{tabular}{|c|c|c|c|c|c|c|c|c|c|c|}
\hline \multirow{3}{*}{ Bulan } & \multicolumn{2}{|c|}{2010} & \multicolumn{2}{|c|}{2011} & \multicolumn{2}{|c|}{2012} & \multicolumn{2}{|c|}{2013} & \multicolumn{2}{|c|}{2014} \\
\hline & $\mathrm{Kec}$ & Arah & $\mathrm{Kec}$ & Arah & $\mathrm{Kec}$ & Arah & $\mathrm{Kec}$ & Arah & $\mathrm{Kec}$ & Arah \\
\hline & (knots) & & (knots) & & (knots) & & (knots) & & (knots) & \\
\hline JAN & 7.85 & 213.16 & 6.56 & 8.08 & 10.94 & 243.25 & 12.33 & 271.28 & 14.16 & 303.22 \\
\hline FEB & 6.81 & 149.77 & 6.76 & 8.03 & 6.56 & 256.51 & 9.78 & 284.85 & 12.23 & 286.00 \\
\hline MAR & 4.69 & 90.27 & 6.96 & 7.98 & 7.14 & 279.15 & 6.78 & 228.68 & 8.37 & 239.02 \\
\hline APR & 4.65 & 8.78 & 7.18 & 7.93 & 3.88 & 152.24 & 4.01 & 179.84 & 4.15 & 209.36 \\
\hline MEI & 4.87 & 8.67 & 7.39 & 7.89 & 6.76 & 155.72 & 4.71 & 166.00 & 4.86 & 145.57 \\
\hline JUNI & 5.08 & 8.58 & 7.60 & 7.85 & 10.19 & 152.00 & 5.34 & 173.04 & 9.43 & 157.52 \\
\hline
\end{tabular}




\begin{tabular}{lrrrrrrrrrr} 
JULI & 5.29 & 8.49 & 7.81 & 7.81 & 12.03 & 146.34 & 7.37 & 165.26 & 12.25 & 159.03 \\
AGS & 5.50 & 8.41 & 8.02 & 7.77 & 13.34 & 142.79 & 11.53 & 146.20 & 11.66 & 142.33 \\
SEP & 5.71 & 8.33 & 8.23 & 7.73 & 11.50 & 147.00 & 9.75 & 145.89 & 11.03 & 141.28 \\
OKT & 5.92 & 8.26 & 8.44 & 7.70 & 4.82 & 178.29 & 6.83 & 179.75 & 7.04 & 135.60 \\
NOV & 6.13 & 8.20 & 8.65 & 7.67 & 4.17 & 231.72 & 4.47 & 223.42 & 4.96 & 196.28 \\
DES & 6.34 & 8.14 & 8.86 & 7.64 & 6.11 & 277.73 & 9.65 & 268.21 & 6.92 & 266.48 \\
\hline
\end{tabular}

Tabel 3. Data Angin Perairan Pantai Barus Tahun 2015-2017 (BMKG Sinaboi)

\begin{tabular}{lrrrrrr} 
& \multicolumn{2}{c}{2015} & \multicolumn{2}{c}{2016} & \multicolumn{2}{c}{2017} \\
\cline { 2 - 7 } Bulan & \multicolumn{1}{c}{ Kec } & Arah & \multicolumn{1}{c}{ Kec } & Arah & \multicolumn{1}{c}{ Kec } & Arah \\
\cline { 2 - 7 } & (knots) & & (knots) & \multicolumn{3}{c}{ (knots) } \\
\hline JAN & 13.82 & 304.35 & 8.54 & 185.19 & 8.52 & 271.53 \\
FEB & 11.92 & 223.16 & 11.62 & 164.10 & 11.82 & 245.00 \\
MAR & 8.50 & 210.73 & 8.60 & 139.36 & 6.39 & 236.69 \\
APR & 4.68 & 189.05 & 3.80 & 158.30 & 5.12 & 204.90 \\
MEI & 7.52 & 152.46 & 4.71 & 181.35 & 8.22 & 139.67 \\
JUNI & 9.14 & 141.78 & 7.76 & 158.95 & 9.81 & 138.09 \\
JULI & 12.92 & 145.83 & 8.31 & 163.63 & 7.01 & 142.80 \\
AGS & 13.10 & 144.99 & 10.92 & 154.88 & 4.82 & 168.96 \\
SEP & 12.58 & 146.32 & 6.90 & 172.89 & 4.48 & 210.25 \\
OKT & 8.12 & 148.05 & 6.24 & 190.22 & 6.24 & 241.51 \\
NOV & 3.53 & 158.69 & 5.35 & 215.04 & 6.79 & 240.95 \\
DES & 9.77 & 220.06 & 5.12 & 142.97 & 9.14 & 294.74 \\
\hline
\end{tabular}

Hasil analisis data angin memutar angin yang terjadi turun dalam angin yang berhembus pada permukaan laut, disajikan setiap tahun untuk Barus dan sekitarnya dalam Tabel 1 - 3. Data angin yang digunakan untuk analisis adalah angin bulanan. Data 12 tahun (2005-2017) menggambarkan kondisi angin pada periode itu.

\subsection{Hasil Analisis Gelombang}

\subsubsection{Perhitungan Fetch Efektif}

Tiap arah mata angin utama meliputi wilayah pengaruh fetch sebesar $22,5^{\circ}$ searah jarum jam dan $22.5^{\circ}$ berlawanan arah jarum jam, seperti terlihat pada Gambar 7 berikut ini. 


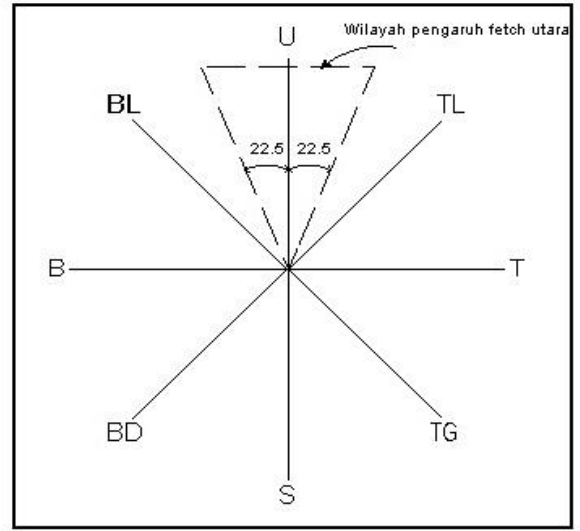

Gambar 7. Contoh Wilayah Pengaruh Fetch untuk Arah Selatan

keterangan :

$\mathrm{F}_{\mathrm{i}} \quad=$ panjang garis fetch untuk sudut interval ke-i

$\theta_{\mathrm{i}} \quad=$ sudut interval

$\mathrm{F}_{\text {eff }} \quad=$ panjang fetch effektif

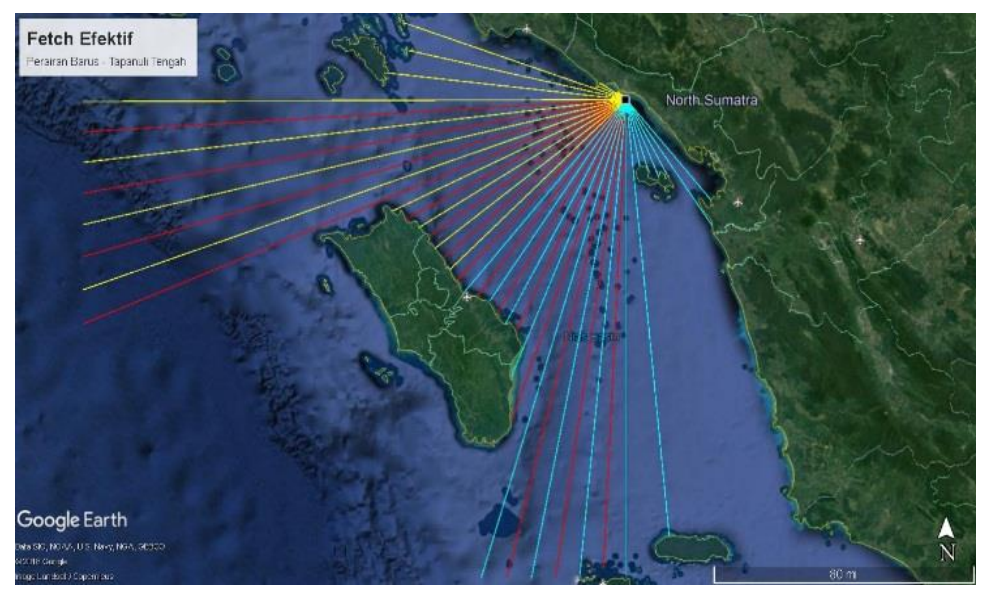

Gambar 8. $\quad$ Peta Fetch di Lokasi Pelabuhan Barus

Tabel 4 adalah data pemrosesan data angin selama 10 tahun, dirangkum menjadi bulanan selama 10 tahun, sehingga peristiwa gelombang ekstrem terjadi pada bulan-bulan tertentu dengan probabilitas peristiwa angin selama 10 tahun.

Tabel 4. Distibusi Gelombang Pertahun Perairan Pantai Barus

\begin{tabular}{ccccccc} 
Tahun & $\mathbf{H}_{\mathbf{1} / \mathbf{3}}(\mathbf{m})$ & $\mathbf{T}_{\mathbf{1} / \mathbf{3}}(\mathbf{d t k})$ & $\mathbf{H}_{\max }(\mathbf{m})$ & $\mathbf{T}_{\max }(\mathbf{d t k})$ & $\mathbf{H}_{\min }(\mathbf{m})$ & $\mathbf{T}_{\min }(\mathbf{d t k})$ \\
\hline 2005 & 1,63 & 5,76 & 2,56 & 6,92 & 0,10 & 1,89 \\
2006 & 1,54 & 5,60 & 2,29 & 6,62 & 0,10 & 1,89 \\
2007 & 1,70 & 5,63 & 2,69 & 7,06 & 0,10 & 1,90 \\
2008 & 1,53 & 5,61 & 2,33 & 6,67 & 0,10 & 1,89
\end{tabular}




\begin{tabular}{ccccccc}
2009 & 1,46 & 5,52 & 2,24 & 6,56 & 0,10 & 1,91 \\
2012 & 1,50 & 5,57 & 2,49 & 6,85 & 0,10 & 1,90 \\
2013 & 1,42 & 5,45 & 2,33 & 6,67 & 0,10 & 1,89 \\
2014 & 1,64 & 5,78 & 2,36 & 6,70 & 0,10 & 1,89 \\
2015 & 1,69 & 5,84 & 2,48 & 6,84 & 0,10 & 1,90 \\
2016 & 1,48 & 5,54 & 2,17 & 6,47 & 0,10 & 1,90 \\
2017 & 0,98 & 4,68 & 2,35 & 6,69 & 0,11 & 1,95 \\
\hline Rata-rata & 1,51 & 5,54 & 2,39 & 6,73 & 0,10 & 1,91 \\
Min & 0,98 & 4,68 & 2,17 & 6,47 & 0,10 & 1,89 \\
\hline
\end{tabular}

Berdasarkan hasil konversi kecepatan dan arah angin menjadi tinggi, periode dan arah gelombang di perairan Barus Tahun 2005-2017 (Tabel 4). Tinggi gelombang signifikan maksimum di perairan Barus terjadi Tinggi gelombang signifikan maksimum di perairan Barus terjadi pada tahun 2007 dengan tinggi gelombang 2,69 meter. Periode gelombang signifikan maksimum di perairan Barus terjadi pada tahun 2007 adalah 7,06 detik.

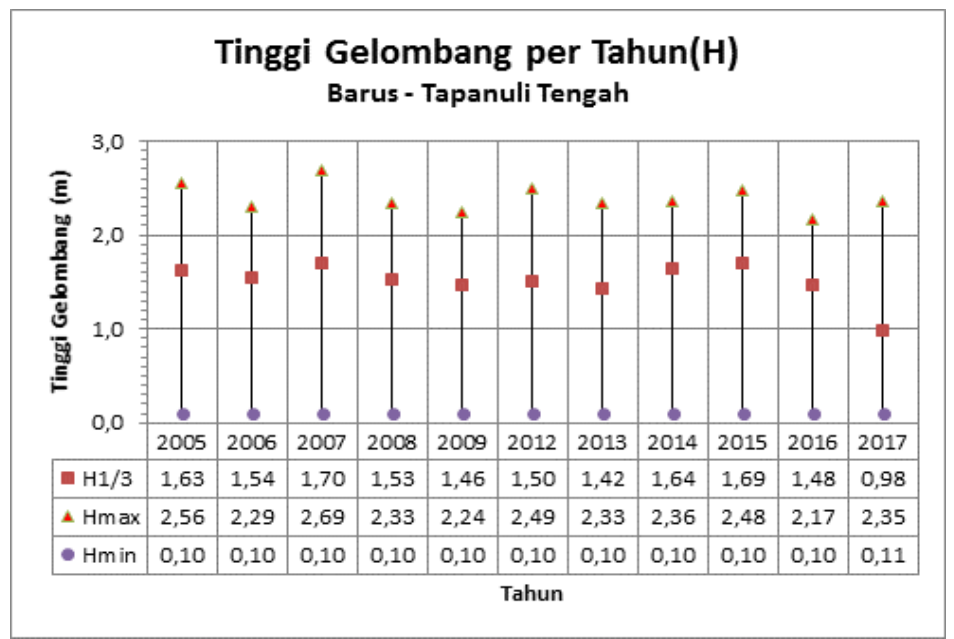

Gambar 9. Tinggi Gelombang Tahunan Perairan Barus Tahun 2006-2016 


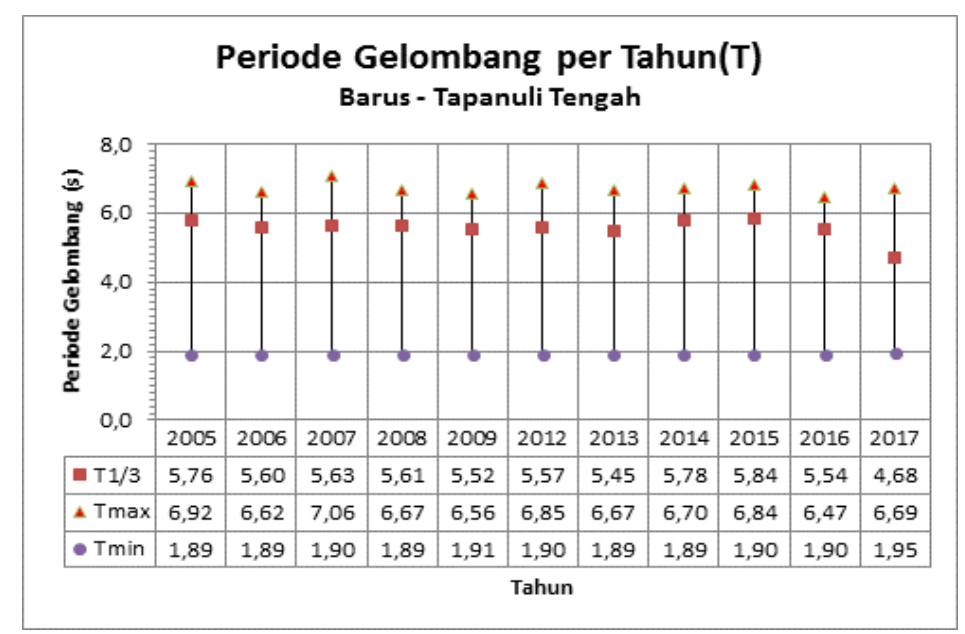

Gambar 10. Periode Gelombang Tahunan Perairan Barus Tahun 2006-2016

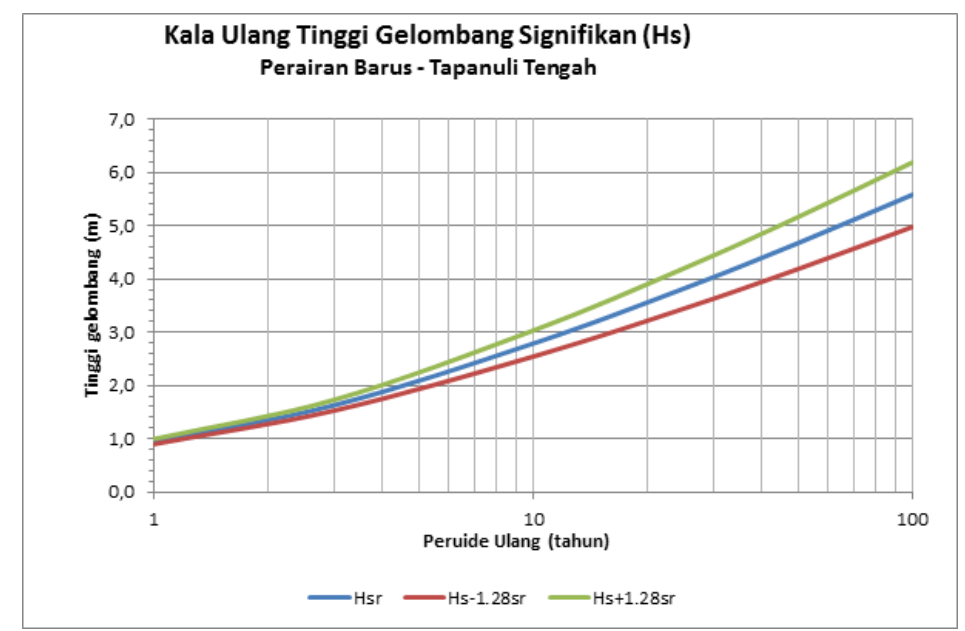

Gambar 11. Kala Ulang Tinggi Gelombang Tahunan Perairan Barus Dengan Tiga Metode Statistik

Berdasarkan analisis statistik dengan metode kekambuhan tinggi gelombang, ketinggian gelombang yang signifikan dapat terjadi atau dilampaui hingga berulang 50 tahun adalah 4,68 $\mathrm{m}$ dengan periode 10,21 detik. Tinggi gelombang maksimum yang terjadi untuk gelombang kala ulang 50 tahun adalah 3,77 m tinggi dengan jangka waktu 7,83 detik. 


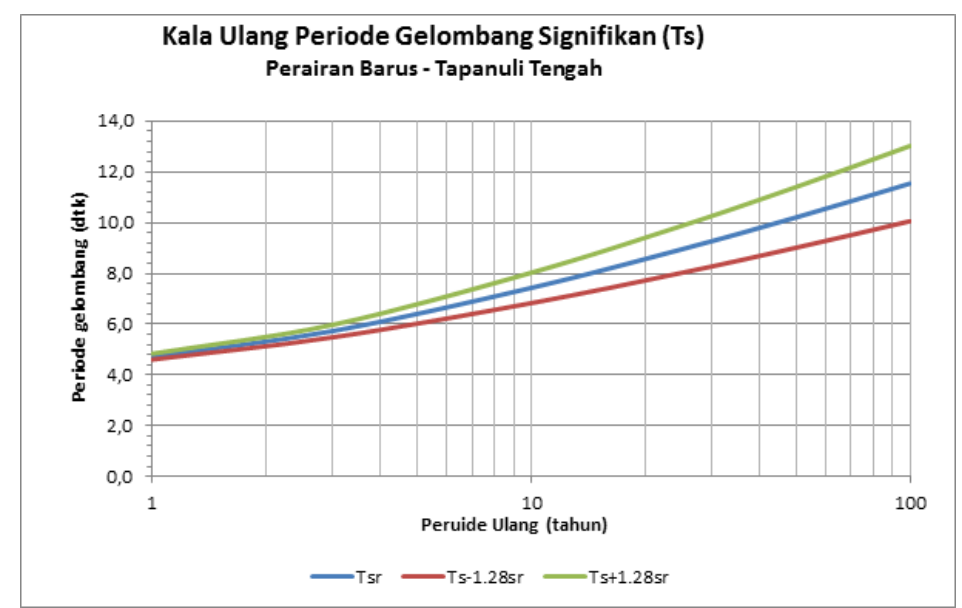

Gambar 12. Kala Ulang Periode Gelombang Tahunan Perairan Barus Dengan Tiga Metode Statistik

Tabel 5. Perbandingan Hasil Kala Ulang Dengan Menggunakan 3 Metode Statistik

\begin{tabular}{ccccc} 
Periode Ulang & $\begin{array}{c}\text { Hs } \\
(\mathrm{m})\end{array}$ & $\begin{array}{c}\text { Ts } \\
(\mathrm{dtk})\end{array}$ & $\begin{array}{c}\text { Hmax } \\
(\mathrm{m})\end{array}$ & $\begin{array}{c}\text { Tmax } \\
(\mathrm{dtk})\end{array}$ \\
\hline 1 & 0,95 & 4,72 & 1,66 & 5,38 \\
3 & 1,63 & 5,73 & 2,05 & 5,83 \\
10 & 2,79 & 7,43 & 2,70 & 6,59 \\
25 & 3,82 & 8,95 & 3,29 & 7,27 \\
50 & 4,68 & 10,21 & 3,77 & 7,83 \\
100 & 5,58 & 11,54 & 4,28 & 8,43 \\
\hline
\end{tabular}

\subsubsection{Permodelan Perubahan Garis Pantai}

Hasil model perubahan garis pantai di lokasi Barus pada kondisi tanpa bangunan pantai diperoleh kondisi maju mundurnya garis pantai seperti tersaji pada Gambar 13 sampai Gambar16. Gambar 13 menunjukkan kondisi awal sebelum dilakukan simulasi, Gambar 14 menunjukkan hasil simulasi selama 1 tahun, Gambar 15 menunjukkan hasil simulasi selama 5 tahun, dan Gambar 16 menunjukan hasil simulasi selama 10 tahun. Berdasarkan hasil model perubahan garis pantai pada tahun ke 0 dibandingkan setelah 10 tahun terjadi perubahan garis pantai sebagai berikut.

1. Sisi timur rusun nelayan terjadi sedimentasi $\pm 3 \mathrm{~m}$

2. Daerah depan rusun nelayan terjadi abrasi $\pm 7 \mathrm{~m}$.

4. Sisi sebelah barat rusun nelayan terjadi abrasi $\pm 3 \mathrm{~m}$.

5. Sisi timur dermaga barus terjadi sedimentasi $\pm 10 \mathrm{~m}$ 
6. Daerah dermaga barus terjadi abrasi $\pm 19 \mathrm{~m}$.

7. Sisi barat dermaga barus terjadi sedimentasi $\pm 8 \mathrm{~m}$.

Gambar 17 menunjukan hasil perbandingan Initial dengan Kondisi tanpa Bangunan. Pada garis merah yang menunjukkan kondisi initial menunjukkan bahwa garis pantai sebagian mengalami maju dan sebagian mengalami mundur, sedangkan pada kondisi yang ditunjukkan garis berwarna biru garis pantai stabil jika dibandingkan dengan kondisi awal.

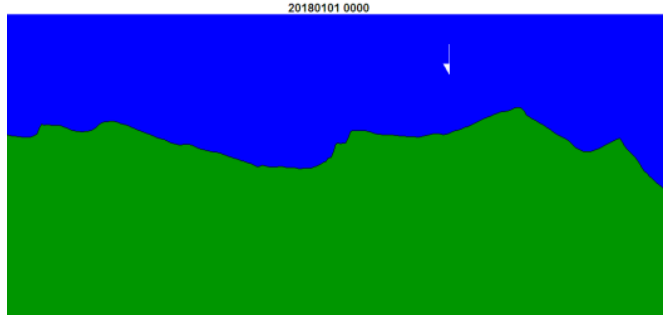

Gambar 13. Model Perubahan Garis Pantai Barus Kondisi Tanpa Bangunan Pantai (Tahun ke 0)

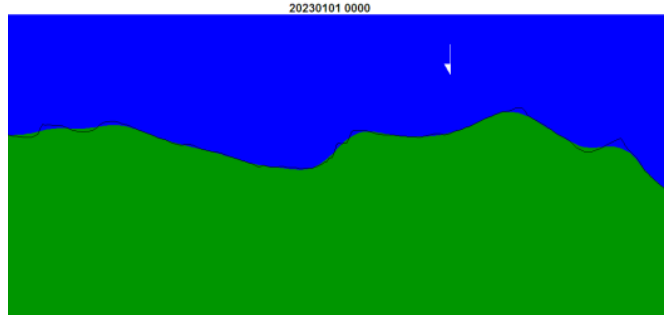

Gambar 15. Model Perubahan Garis Pantai Barus Kondisi Tanpa Bangunan Pantai (Tahun ke 5)

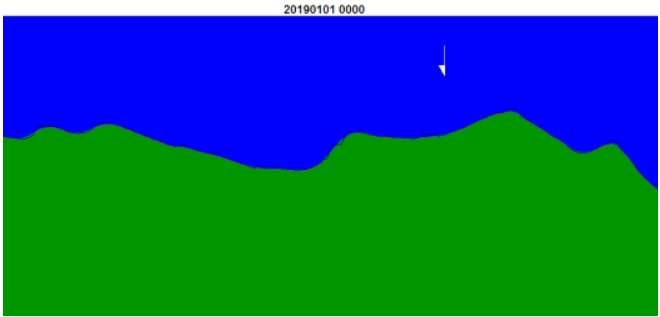

Gambar 14. Model Perubahan Garis Pantai Barus Kondisi Tanpa Bangunan Pantai (Tahun ke 1)

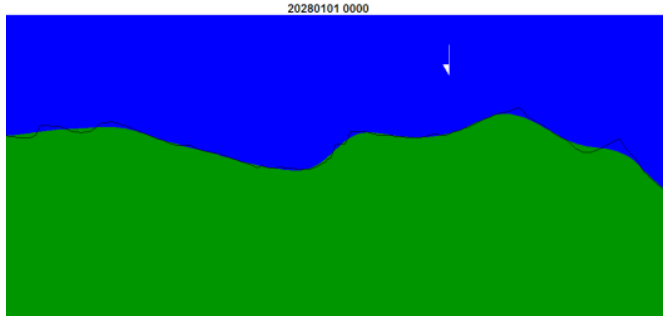

Gambar 16. Model Perubahan Garis Pantai Barus Kondisi Tanpa Bangunan Pantai (Tahun ke 10)

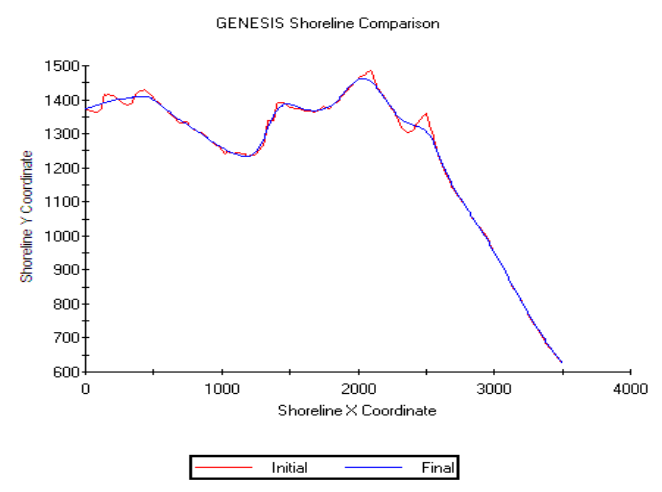

Gambar 17. Grafik Perubahan Garis Pantai Intial vs Final Pantai Barus Kondisi Tanpa Bangunan Pantai (Tahun ke 10)

Hasil model perubahan garis pantai di lokasi Barus pada kondisi dengan penambahan jetty pada dermaga Barus dan krib di daerah rusun nelayan disajikan pada 
Gambar 18 sampai Gambar 20. Gambar 18 menunjukkan hasil simulasi selama 1 tahun, Gambar 19 menunjukkan hasil simulasi selama 5 tahun, dan Gambar 20 menunjukan hasil simulasi selama 10 tahun. Berdasarkan hasil model perubahan garis pantai setelah dilakukan simulasi selama 10 tahun menunjukkan bahwa

1. Sisi timur rusun nelayan terjadi abrasi $\pm 7 \mathrm{~m}$ dan sedimentasi $\pm 5 \mathrm{~m}$.

2. Daerah depan rusun nelayan terjadi sedimentasi $\pm 5 \mathrm{~m}$.

3. Sisi barat rusun nelayan terjadi sedimentasi $\pm 20 \mathrm{~m}$.

4. Di sisi timur dermaga barus terjadi abrasi $\pm 30 \mathrm{~m}$.

5. Daerah dermaga barus terjadi sedimentasi $\pm 20 \mathrm{~m}$.

6. Sisi barat dermaga barus terjadi sedimentasi $\pm 9 \mathrm{~m}$.

Gambar 21 menunjukan hasil perbandingan kondisi garis pantai eksisting dan setelah ada bangunan. Pada garis merah yang menunjukkan kondisi eksisting menunjukkan bahwa garis pantai sebagian mengalami maju dan sebagian mengalami mundur, sedangkan pada kondisi setelah ada bangunan yang ditunjukkan garis berwarna biru, kondisi garis pantai stabil jika dibandingkan dengan kondisi awal.

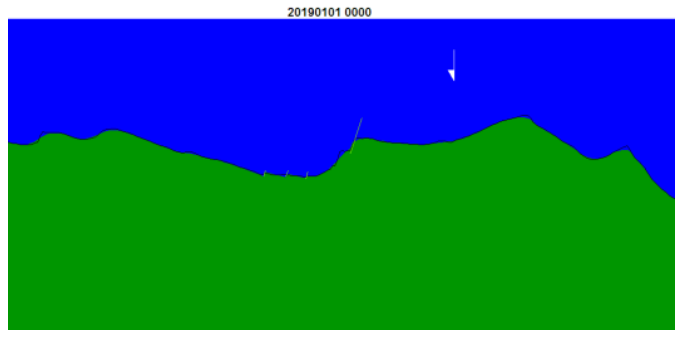

Gambar 18. Model Perubahan Garis Pantai Barus Kondisi Penambahan Jetty dan Krib (Tahun ke 1)

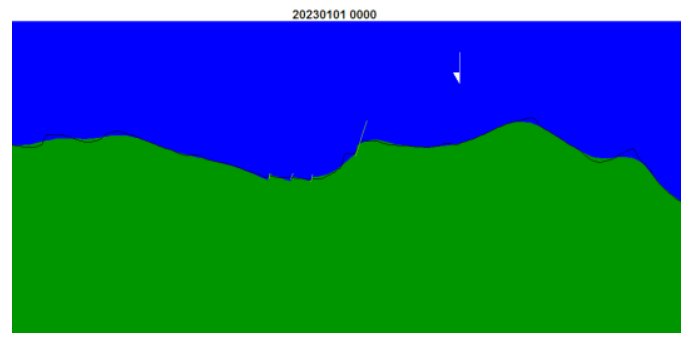

Gambar 19. Model Perubahan Garis Pantai Barus Kondisi Tanpa Bangunan Pantai (Tahun ke 5)

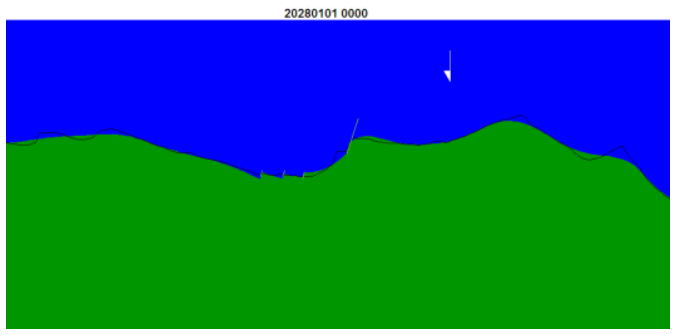

Gambar 20. Model Perubahan Garis Pantai Barus Kondisi Tanpa Bangunan Pantai (Tahun ke 10) 


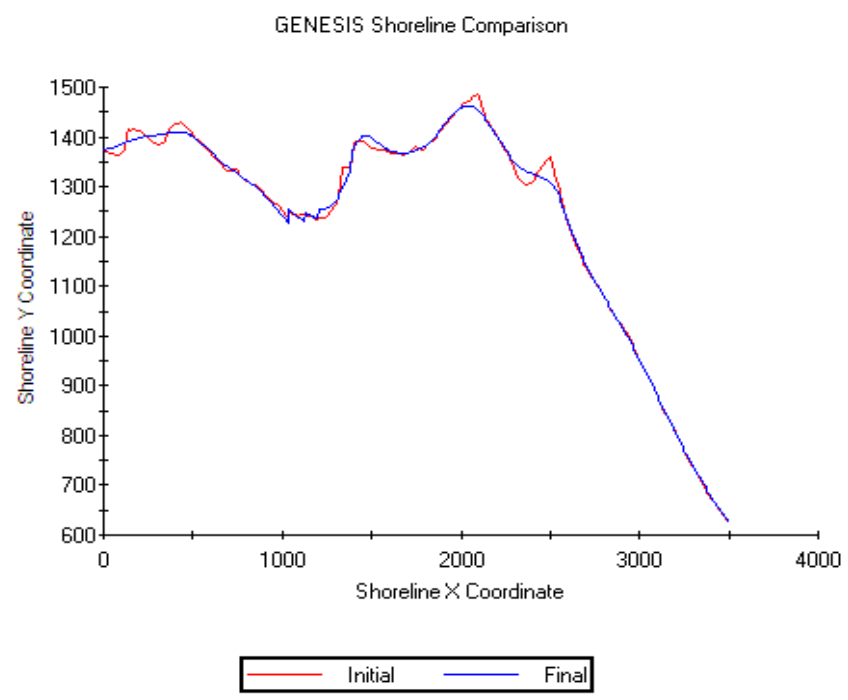

Gambar 21. Grafik perubahan garis pantai initial vs final pantai Barus kondisi dengan penambahan Jetty dan krib (tahun ke 10)

Hasil model perubahan garis pantai di lokasi Barus pada kondisi dengan penambahan jetty pada dermaga Barus, krib di daerah rusun nelayan, dan penambahan seawall di depan rusun dan sebelah Barat Dermaga Barus tersaji pada Gambar 22 sampai Gambar 24. Gambar 22 menunjukkan hasil simulasi selama 1 tahun, Gambar 23 menunjukkan hasil simulasi selama 5 tahun, dan Gambar 24 menunjukan hasil simulasi selama 10 tahun Berdasarkan hasil model perubahan garis pantai selama 10 tahun menunjukkan bahwa

1. Sisi sebelah timur rusun nelayan terjadi abrasi $\pm 7 \mathrm{~m}$ dan sedimentasi $\pm 5 \mathrm{~m}$.

2. Daerah depan rusun nelayan tidak terjadi sedimentasi maupun abrasi.

3. Sisi sebelah barat rusun nelayan tidak terjadi sedimentasi maupun abrasi.

4. Sisi timur dermaga barus tidak terjadi abrasi maupun sedimentasi.

5. Daerah dermaga barus terjadi sedimentasi $\pm 20 \mathrm{~m}$.

7. Sisi barat dermaga barus terjadi sedimentasi $\pm 9 \mathrm{~m}$.

Gambar 25 menunjukan hasil perbandingan kondisi garis pantai eksisting dan penambahan bangunan jetty, krib dan seawall. Pada garis merah yang menunjukkan kondisi eksisting menunjukkan bahwa garis pantai sebagian mengalami maju dan sebagian mengalami mundur, sedangkan pada kondisi setelah ada bangunan yang ditunjukkan garis berwarna biru, kondisi garis pantai stabil jika dibandingkan dengan kondisi awal. 


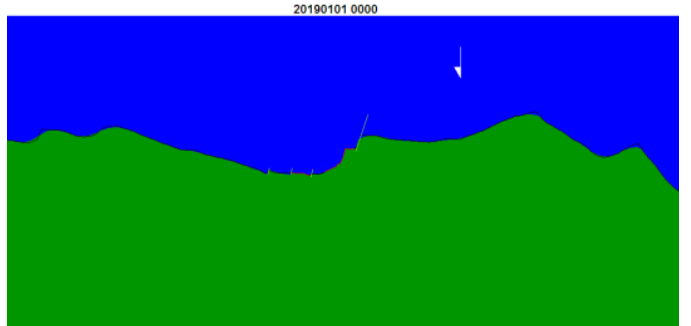

Gambar 22. Model Perubahan Garis Pantai Barus Kondisi Penambahan Jetty dan Krib dan Seawall (Tahun ke 1)

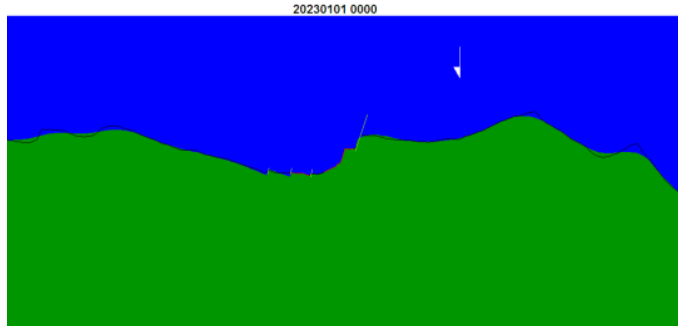

Gambar 23. Model Perubahan Garis Pantai Barus Kondisi Penambahan Jetty dan Krib dan Seawall (Tahun ke 5)

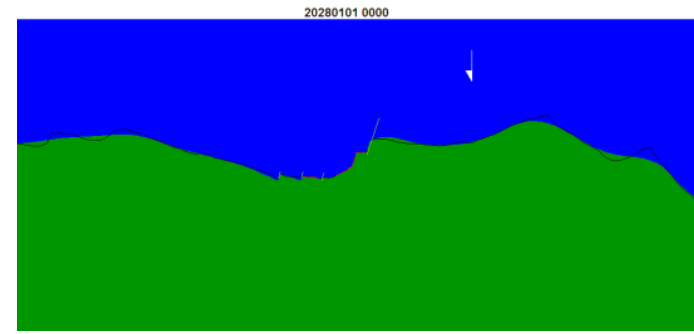

Gambar 24. Model Perubahan Garis Pantai Barus Kondisi Penambahan Jetty dan Krib dan Seawall (Tahun ke 10)

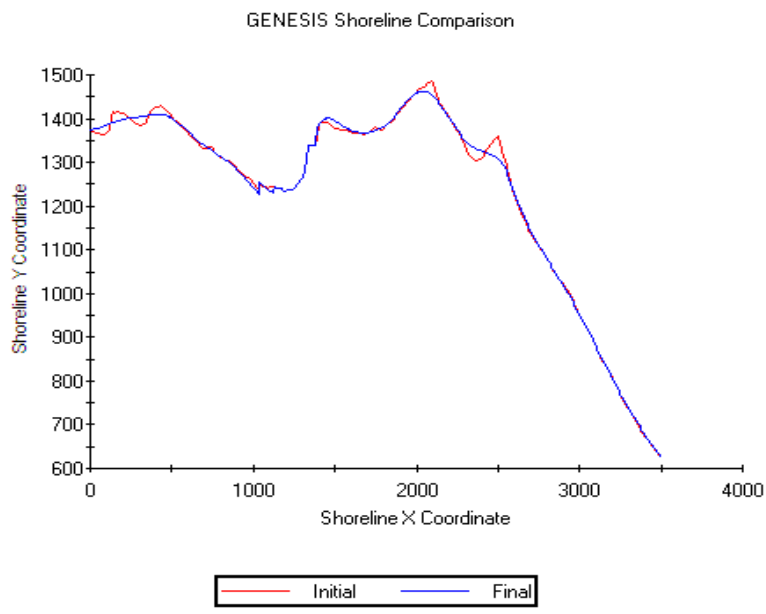

Gambar 25. Grafik perubahan garis pantai initial vs final pantai Barus kondisi dengan penambahan Jetty dan krib dan seawall (tahun ke 10)

\section{KESIMPULAN}

Berdasarkan hasil permodelan perubahan garis pantai adalah sebagai berikut :

1. Suplai sedimen yang berasal dari Sungai Sirahaan tertahan dengan adanya bangunan jetty masif milik dermaga, sehingga pergerakan sedimen yang masuk dan keluar di perairan sisi timur sungai Sirahan tidak seimbang. 
2. Pergerakan sedimen yang keluar akibat gelombang lebih besar dibandingkan dengan suplai dari sungai Sirahan, sehingga garis pantai mengalami kemunduran.

Hasil simulasi perubahan garis pantai untuk kondisi penanganan dengan membuat tembok laut di depan kawasan rusun menunjukkan bahwa lokasi tersebut aman terhadap gerusan gelombang.

\section{DAFTAR PUSTAKA}

. 2018. Data Angin Kota Sinaboi Tahun 2005-2017. Badan Meteorologi Klimatologi dan Sinaboi, Tapanuli Tengah.

Coastal Engineering Research Center. (1984). Waterways Experiment Station, Corps of Engineer, Department of The Army, Shore Protection Manual.

Coastal Engineering Research Center. (1984). Waterways Experiment Station, Corps of Engineer, Department of The Army (2001), Coastal Engineering Manual.

Coastal Engineering Research Center. (2006). Waterways Experiment Station, Corps of Engineer, Department of The Army, Coastal Engineering Manual.

Jesica D, dkk. Analisis Perubahan Garis Pantai Desa Rutong Kota Ambon, Jurnal Teknik Sipil, Universitas Kristen Maranatha,vol 14 no 2 th 2018.

Purwono N.A.S. Analisa Kejadian Gelombang dengan Metode Empirik dan Model Matematik di Kawasan Perairan Pelabuhan Tanjung Laut, Gorontalo Journal of Infrastructure and Science Engineering, vol 3 no 1 th 2020.

Purwono N.A.S, dkk. Characteristics of High Growth Casuarina Equisetifolia and HighInudation of Tsunami when Propagation Through Greenbelt Vertical Rod, Applied Mechanics and Materials International Journal, Main Theme Ocean Science and Coastal Engineering, Chapter 1: Hidrodynamics and Morphodynamics vol 862 pp 21-26, Publishing Scientific. NetZurich Switzerland, 2017

Purwono N.A.S. dkk. Peramalan Kejadian Gelombang Watunohu dengan Pendekatan Empiris Analisa Data Angin, Jurnal Teodolita, vol 19 no 2 th 2018.

Triatmodjo Bambang. (2012). Perencanaan Bangunan Pantai, Beta Ofset, Yogyakarta. Triatmodjo Bambang. (1999). Teknik Pantai, Beta Ofset, Yogyakarta.

Yuwono Nur. (2020). Teknik Pelindungan dan Pengamanan Wilayah pesisir. Kanisius. Yogyakarta. 